\title{
Pseudoalteromonas tunicata sp. nov., a bacterium that produces antifouling agents
}

\author{
Carola Holmström, ${ }^{1}$ Sally James, ${ }^{1}$ Brett A. Neilan, ${ }^{1}$ David C. White ${ }^{2}$ \\ and Staffan Kjelleberg ${ }^{1}$
}

\author{
Author for correspondence: Carola Holmström. Tel: +6129385 2601. Fax: +61293851591. \\ e-mail: c.holmstrom answ.edu.au
}

\begin{abstract}
1 School of Microbiology and Immunology, The University of New South Wales, Sydney 2052, Australia

2 Center for Environmental Biotechnology, University of Tennessee, 10515 research Drive, Suite 300 , Knoxville, TN 37932, USA
\end{abstract}

\begin{abstract}
A dark-green-pigmented marine bacterium, previously designated D2, which produces components that are inhibitory to common marine fouling organisms has been characterized and assessed for taxonomic assignment. Based on direct double-stranded sequencing of the 16S rRNA gene, $\mathrm{D2}^{\top}$ was found to show the highest similarity $(93 \%)$ to members of the genus Pseudoalteromonas. The $\mathrm{G}+\mathrm{C}$ content of $\mathrm{D2}^{\mathrm{T}}$ is $\mathbf{4 2} \mathrm{mol} \%$, and it is a facultatively anaerobic rod and oxidase-positive. $\mathrm{D2}^{\mathrm{T}}$ is motile by a sheathed polar flagellum, exhibited non-fermentative metabolism and required sodium ions for growth. The strain was not capable of using citrate, fructose, sucrose, sorbitol and glycerol but it utilizes mannose and maltose and hydrolyses gelatin. The molecular evidence, together with phenotypic characteristics, showed that this bacterium which produces an antifouling agent constitutes a new species of the genus Pseudoalteromonas. The name Pseudoalteromonas tunicata is proposed for this bacterium, and the type strain is $\mathrm{D2}^{\mathrm{T}}$ ( = CCUG 26757').
\end{abstract}

Keywords: Pseudoalteromonas tunicata, pigment, antifouling bacterium, marine, $16 \mathrm{~S}$ rRNA sequence

\section{INTRODUCTION}

Heterotrophic bacteria which are Gram-negative and motile through the use of flagella are commonly isolated from marine environments. These culturable bacteria can be divided into two groups based on their capacity to ferment carbohydrates. The fermentative strains belong to the genera Vibrio, Listonella, Photobacterium. Colwellia and Aeromonas and the nonfermentative strains belong to Alteromonas, Pseudomonas, Alcaligenes, Halomonas, Deleya, Marinomonas, Shewanella and Flavobacterium (Kita-Tsukamoto et al., 1993). The two new genera Listonella and Colwellia have been suggested for species formerly considered to be members of the genus Vibrio (Deming et al., 1988; MacDonell \& Colwell, 1985) while most members of the genus Alteromonas have been reclassified within the new genus Pseudoalteromonas (Gauthier et al., 1995)

Gauthier et al. (1995) made a comparison of the phylogenetic relationships among 17 isolates of the genera Alteromonas, Shewanella and Moritella. The

The GenBank accession number for the 165 rDNA sequence of strain $D 2^{\top}$ is Z25522. results suggested that the genus Alteromonas should be separated into two genera. The new genus was designated Pseudoalteromonas. Originally the genus $\mathrm{Al}$ teromonas contained four species and was created for marine bacteria that are Pseudomonas-like but which have a lower $G+C$ content (Baumann et al., 1972). The new genus, Pseudoalteromonas, was recommended to contain 11 species previously belonging to species of Alteromonas and one species that previously was placed in the genus Pseudomonas, Pseudoalteromonas piscicida comb. nov. (Gauthier et al., 1995). The genus Alteromonas is thereby restricted to a single species, Alteromonas macleodii.

The strain in this study, a pigmented Gram-negative marine bacterium, designated $\mathrm{D} 2^{\mathrm{T}}(\mathrm{T}=$ type strain), was isolated from an adult tunicate, Ciona intestinalis. The bacterium was shown to produce extracellular components that kill the larvae of Balanus amphitrite and Ciona intestinalis (Holmström et al., 1992). In addition, recent studies have demonstrated that the isolate produces at least four different extracellular compounds with various degrees of specific inhibitory activity against a variety of organisms including bacteria, algae, diatoms and fungi (Egan, 1995; Holmström et al., 1992, 1996, 1997; Holmström \& 
Kjelleberg, 1994; James et al., 1996). In this study, we carried out a phenotypic and genetic characterization of the isolate for taxonomic classification. The nonfermentative nature of this strain precludes its inclusion in the genus Vibrio, and the $\mathrm{G}+\mathrm{C}$ content of the genome is too low for the inclusion in the genera Pseudomonas and Marinomonas. Isolate $\mathrm{D} 2^{\mathrm{T}}$ revealed $93.4 \% 16 \mathrm{~S}$ rDNA sequence similarity to the next closest related bacterial strain (Pseudoalteromonas citrea) in current DNA sequence databases (GenBank, EMBL and RDP). This relationship is well within the range of $\%$ similarities of the genus Pseudoalteromonas $(>91 \%)$. We therefore propose isolate $\mathrm{D} 2^{\mathrm{T}}$ as a new species of the genus Pseudoalteromonas, P. tunicata on the basis of its physiological, biochemical and genetic features.

\section{METHODS}

Bacterial strain and isolation. Strain $\mathrm{D} 2^{\mathrm{T}}$ was isolated from an adult tunicate Ciona intestinalis which was collected from a depth of $10 \mathrm{~m}$ in Gullmarsfjorden on the western coast of Sweden. A platinum loop was used to obtain samples from the surface of tunicates and loopfuls of the samples were diluted in sterile nine salt solution (NSS, which consists of, per litre, $17.6 \mathrm{~g} \mathrm{NaCl}, 1.47 \mathrm{~g} \mathrm{Na}_{2} \mathrm{SO}_{4}, 0.08 \mathrm{~g} \mathrm{NaHCO}_{3}, 0.25 \mathrm{~g}$ $\mathrm{KCl}, 0.04 \mathrm{~g} \mathrm{KBr}, 1.87 \mathrm{~g} \mathrm{MgCl}_{2} .6 \mathrm{H}_{2} \mathrm{O}, 0.41 \mathrm{~g} \mathrm{CaCl}_{2} .2 \mathrm{H}_{2} \mathrm{O}$, $\left.0.008 \mathrm{~g} \mathrm{SrCl} .6 \mathrm{H}_{2} 0,0.008 \mathrm{~g} \mathrm{H}_{3} \mathrm{BO}_{3}, \mathrm{pH} 7\right)$. Aliquots of the diluted samples were spread on VNSS agar plates (VNSS agar consists of per litre NSS, $1.0 \mathrm{~g}$ peptone, $0.5 \mathrm{~g}$ yeast extract, $0.5 \mathrm{~g}$ glucose, $0.01 \mathrm{~g} \mathrm{FeSO}_{4} .7 \mathrm{H}_{2} \mathrm{O}, 0.01 \mathrm{~g} \mathrm{Na}_{2} \mathrm{HPO}_{4}$ and $15 \mathrm{~g}$ agar) and incubated for $3-5 \mathrm{~d}$ at $20^{\circ} \mathrm{C}$. Isolates were maintained on VNSS agar plates at $4{ }^{\circ} \mathrm{C}$. Bacteria were also stored at $-70^{\circ} \mathrm{C}$ in $30 \%(\mathrm{v} / \mathrm{v})$ glycerol. Isolate $\mathrm{D} 2^{\mathrm{T}}(=$ CCUG 26757 ) has been deposited in the Culture Collection of the University of Göteborg. All media used in this study were sterilized at $121^{\circ} \mathrm{C}$ for $20 \mathrm{~min}$, unless otherwise stated.

Phenotypic characterization of strain $\mathrm{D} 2^{\top}$. The bacterium was routinely grown on the complex marine medium, VNSS, and incubated at $20^{\circ} \mathrm{C}$ to provide inocula for the biochemical tests.

Oxidative or fermentative utilization of glucose was determined by the method of Hugh \& Leifson (1953). Catalase activity was determined by the methods of Skerman (1967) and oxidase activity was tested by the Kovaks method (Kovaks, 1956).

The salinity tests were performed using the medium VNSS with $\mathrm{NaCl}$ concentrations ranging from 0 to $10 \%(\mathrm{w} / \mathrm{v})$. We also tested for growth on Tryptone soy broth (TSB) (Oxoid) and Luria broth (LB 20) supplemented with $2 \%$ salt (w/v) (Östling et al., 1991). A marine minimal medium (MMM) (Östling et al., 1991) was used during tests of growth of D2 ${ }^{\mathrm{T}}$ on different substrates as sole carbon and energy sources at the concentration of $4 \mathrm{~g}^{-1}$.

Swarming (Givskov et al., 1996) was tested on four different media, VNSS, TSB, LB 20 and AB (Clark \& Maaloe, 1967). The last medium was supplemented with $0.4 \%$ glucose, $0.5 \%$ Casamino acids, and all four media were supplemented with $0.6 \%$ Bacto agar.

The susceptibility of strain D2 ${ }^{\mathrm{T}}$ to the antibiotics (Bauer et al., 1966) erythromycin, rifampicin, gentamicin, tetracycline, ampicillin, neomycin, kanamycin and nalidixic acid was tested at $100 \mu \mathrm{g} \mathrm{ml}^{-1}$ and its sensitivity to the vibriostatic agent $0 / 129$ was tested at a concentration of $150 \mu \mathrm{g} \mathrm{ml}^{-1}$. Disks $(6.0 \mathrm{~mm}$ in diameter) impregnated with antibiotics were placed on VNSS agar plates which had been surfaceinoculated with $\mathrm{D} 2^{\mathrm{T}}$ suspension.

Some of the biochemical properties of the isolate were determined using the API 20E system (Analytab Products) and exponential-phase bacterial cells which were washed three times in minimal medium (MMM) before being inoculated into the test cupules.

The motility of the cells was determined with a $100 \times$ oilimmersion objective.

Negative staining and electron microscopy. Cell morphology and size and the presence and type of flagellum were examined by using cells from an $18 \mathrm{~h}$ bacterial growth culture. The cells were suspended in a fixative $(2.5 \%$ glutaraldehyde in $0.1 \mathrm{M}$ sodium cacodylate buffer), fixed for $30 \mathrm{~min}$, and washed three times in sterile Milli-Q water. A drop of the cell suspension was mixed with one drop of sodium phosphotungstate stain ( $2 \%$ aqueous) for $10 \mathrm{~s}$ using a Formvar grid (300-square copper grid). The grid was thereafter blotted with filter paper and dried for $10 \mathrm{~min}$ before examination using a Hitachi $\mathrm{H} 7000$ electron microscope operated at $75 \mathrm{kV}$.

Fatty acid analysis. D2 ${ }^{\mathrm{T}}$ was grown on VNSS medium at $25^{\circ} \mathrm{C}$ for $24 \mathrm{~h}$. The cells were harvested, washed, and freezedried. The supernatant was collected and filtered through a $0.22 \mu \mathrm{m}$ filter and thereafter freeze-dried. A modified BlighDyer lipid extraction (Bligh \& Dyer, 1959; White et al., 1979) was performed on the extracts followed by silicic acid chromatography to fractionate the lipids. Finally mild alkaline methanolysis was performed (White et al., 1979). The samples were then separated, quantified and identified by capillary gas-liquid chromatography/electron impact mass spectrometry (Guckert et al., 1985). The results were based on three replicates.

Genome analysis. The $\mathrm{G}+\mathrm{C}$ content was determined by using a thermal denaturation procedure (Johnson, 1994). The DNA samples used for the analysis were extracted and purified as described by Wilson (1992) and the results were based on four replicates. Pseudoalteromonas haloplanktis ACAM 547 was used as a reference strain $(\mathrm{G}+\mathrm{C}=$ $43.0 \mathrm{~mol} \%$ ).

$16 S$ rDNA amplification and sequencing. Bacterial cells for the DNA extraction were grown in a complex marine medium VNSS and harvested ( $1.5 \mathrm{ml}$ bacterial suspension) in late-exponential phase of growth. The DNA extraction, PCR-mediated amplification of the 16S rDNA and purification of PCR products were carried out as described previously by Hallbeck et al. (1993). Both strands were sequenced with the Sequenase version 2.0 DNA sequencing kit (USB). The PCR product was sequenced directly, using the primers as described by Hallbeck et al. (1993).

Nucleotide sequence accession numbers. EMBL/GenBank/ RDP accession numbers (in parentheses) for small-subunit rDNA sequences of strains other than D2 ${ }^{\mathrm{T}}$ used in this study are as follows: Alteromonas macleodii IAM $12920^{\mathrm{T}}$ (X82145), Marinomonas vaga ATCC 27119 (X67025), Moritella marinus NCIMB $1144^{\mathrm{T}}$ (X82142), Pseudoalteromonas antarctica CECT4664 ${ }^{\mathrm{T}}$ (X98336), Pseudoalteromonas atlantica IAM $12927^{\mathrm{T}}$ (X82134), Pseudoalteromonas aurantia ATCC $33046^{\mathrm{T}}$ (X82135), Pseudoalteromonas carrageenovora IAM 12662 (X82136), Pseudoalteromonas citrea NCIMB $1889^{\mathrm{T}}$ (X82137), Pseudoalteromonas denitrificans ATCC 43337 $7^{\mathrm{T}}$ (X82138), Pseudoalteromonas espejiana NCIMB 
2127 (X82143), Pseudoalteromonas haloplanktis subsp. haloplanktis ATCC 14393 ${ }^{\mathrm{T}}$ (X67024), Pseudoalteromonas luteoviolacea NCIMB 1893' (X82144), Pseudoalteromonas nigrifaciens: NCIMB 8614 ${ }^{\mathrm{T}}$ (X82135), Pseudoalteromonas piscicida ATCC $15057^{\mathrm{T}}$ (X82215), Pseudoalteromonas rubra ATCC 29570 (X82147), Pseudoalteromonas haloplanktis subsp. tetraodonis IAM $14160^{\mathrm{T}}$ (X82139), Pseudoalteromonas undina NCIMB 2128 ${ }^{\mathrm{T}}$ (X82140), Pseudoalteromonas sp. IC006 (U85856), Pseudoalteromonas sp. IC013 (U85859), Pseudoalteromonas sp. MB6-05 (U85860), Pseudoalteromonas sp. MB6-03 (U85857), Pseudoalteromonas sp. MB811 (U85855), Pseudoalteromonas sp. SW08 (U85861), Pseudoalteromonas sp. SW29 (U85862), Pseudoalteromonas sp. S9 (U80834), Pseudoalteromonas sp. Y (AF030381), Pseudoalteromonas sp. ANG.RO2 (AF022407), Pseudoalteromonas peptidysin $\mathrm{F} 12-50-\mathrm{Al}^{\mathrm{T}}$ (AF007286), Shewanella benthica ATCC 43992 (X82131), Shewanella hanedai CIP $103207^{\mathrm{T}}$ (X82132), Shewanella putrefaciens ATCC 8071 (X82133), Aeromonas allosaccharophila CECT $4199^{\mathrm{T}}$ (S39232), Photobacterium sp. SS9 (U91586), Vibrio fischeri ATCC 7744 (X74702) and Escherichia coli (J01859). Culture collection designations are: ATCC, American Type Culture Collection, Rockville, MD, USA; NCIMB, National Collection of Industrial and Marine Bacteria, Aberdeen, UK; IAM, Institute of Applied Microbiology, Tokyo, Japan; CIP, Collection of Institute Pasteur, Paris, France.

Phylogenetic analysis. DNA sequences were aligned using the programs PILEUP, GCG (Wisconsin package, 1994) and the multiple sequence alignment tool from CLUSTAL $W$ (Thompson et al., 1994). Manual confirmation of the sequence alignment was performed and checked against both primary and secondary structure considerations of the 16S rRNA molecule. The aligned sequences were applied to genetic distance and maximum parsimony methods for phylogenetic inference. For all multiple sequence alignments and phylogenetic inference programs the input order of taxa was randomized. Genetic distances were calculated using the formula of Jukes \& Cantor (1969), where $D=-3 / 4$ $\ln (1-4 / 3 d)$ and $d$ is the sequence dissimilarity. Phylogenetic inference protocols, DNADIST, NEIGHBOR, DNAPARS, CONSENSE and SEQBOOT were supplied by the PHYLIP package (version $3.57 \mathrm{c}$ ) (Felsenstein, 1989). All sequence manipulation and phylogeny programs were made available through the Australian National Genome Information Service (ANGIS, Sydney, Australia).

\section{RESULTS}

\section{Phenotypic characterization of the marine isolate}

Strain D2 2 grew at $4{ }^{\circ} \mathrm{C}$ but not at $37{ }^{\circ} \mathrm{C}$, with optimal growth at approximately $28^{\circ} \mathrm{C}$. Growth at the lower temperatures of 4 and $10^{\circ} \mathrm{C}$ was very slow compared with that at $28^{\circ} \mathrm{C}$. The water temperature surrounding the tunicate specimen, at the time of the isolation, was approximately $10^{\circ} \mathrm{C}$. D2 $2^{\mathrm{T}}$ tolerated a $\mathrm{pH}$ range of 5.5-9 (optimum pH 7-8) while the low-molecular-mass component, which is active against invertebrate larvae, tolerated a $\mathrm{pH}$ range of 2-11 without losing its inhibitory activity (Holmström, 1993). D2 ${ }^{\mathrm{T}}$ required $\mathrm{Na}^{+}$at a concentration of $0.3 \%(\mathrm{w} / \mathrm{v}) \mathrm{NaCl}$, and optimal salinity for growth of the strain was found to be $1-2 \%(\mathrm{w} / \mathrm{v}) \mathrm{NaCl}$ concentration.

The isolate exhibited gelatinase activity while $\beta$ -
Table 1. Phenotypic characteristics of Pseudoalteromonas tunicata

- , Negative; + , positive.

\begin{tabular}{|c|c|}
\hline Characteristic & P. tunicata \\
\hline Swarming & - \\
\hline Growth at $4{ }^{\circ} \mathrm{C}$ & + \\
\hline Growth at $37^{\circ} \mathrm{C}$ & - \\
\hline Optimal $\mathrm{NaCl}$ concentration $(\%)$ & $1-2$ \\
\hline Optimal pH & $7-8$ \\
\hline Hugh-Leifson test & - \\
\hline \multicolumn{2}{|l|}{ Production of: } \\
\hline$\beta$-Galactosidase activity & - \\
\hline Arginine dihydrolase activity* & - \\
\hline Lysine decarboxylase activity* & - \\
\hline Ornithine decarboxylase activity* & - \\
\hline \multicolumn{2}{|l|}{ Hydrolysis of: } \\
\hline Urease & - \\
\hline Gelatin & + \\
\hline \multicolumn{2}{|l|}{ Utilization of: } \\
\hline Glucose, maltose, trehalose & + \\
\hline Mannose & $+\dagger$ \\
\hline $\begin{array}{l}\text { Galactose, fructose, xylose, sucrose, } \\
\text { lactose, raffinose, melibiose, rhamnose, } \\
\text { arabinose, glycerol, mannitol, sorbitol, } \\
\text { inositol, dulcitol, melizitose, xylitol, } \\
\text { erythritol, glycine, citrate }\end{array}$ & - \\
\hline DL-Threonine & - \\
\hline L-Asparagine & - \\
\hline L-Proline & $+\dagger$ \\
\hline L-Histidine & - \\
\hline Tween 20 & + \\
\hline Oxidase & + \\
\hline Catalase & + \\
\hline Sheathed polar flagellum & + \\
\hline $\mathrm{G}+\mathrm{C}$ content $(\mathrm{mol} \%)$ & $42 \cdot 2 \pm 0 \cdot 7$ \\
\hline
\end{tabular}

* Tests using the API 20E system.

$\uparrow$ Growth after $48 \mathrm{~h}$.

galactosidase, arginine dihydrolase, lysine-ornithine decarboxylase and urease activities were not detected. Did not show any $\mathrm{H}_{2} \mathrm{~S}$ or $\mathrm{NO}_{2}$ production. Growth on different carbon and energy sources showed that the bacterium utilizes trehalose, glucose, maltose and Tween 20 after $24 \mathrm{~h}$ incubation and mannose and proline after $48 \mathrm{~h}$. We have not been able to demonstrate growth on additional carbohydrates or amino acids. It did not ferment sugar in the Hugh--Leifson test and the cells were sensitive to erythromycin, rifampicin, gentamicin, tetracycline, ampicillin, neomycin, kanamycin and nalidixic acid at concentrations of $100 \mu \mathrm{g} \mathrm{ml}^{-1}$. The isolate is sensitive to the vibriostatic agent $0 / 129$ at a concentration of $150 \mu \mathrm{g}$ and is oxidase and catalase-positive. Strain $\mathrm{D} 2^{\mathrm{T}}$ cells are $2 \cdot 0-3.4 \mu \mathrm{m}$ in length, motile and rod-shaped, and possess a single sheathed polar flagellum. Swarming of the bacteria was not detected (Table 1). 
Table 2. Fatty acid profiles of cell and supernatant extracts of $P$. tunicata

Results are expressed as mean $\mathrm{mol} \%( \pm \mathrm{SD})$.

\begin{tabular}{|c|c|c|}
\hline \multirow[t]{2}{*}{ Fatty acid } & \multicolumn{2}{|c|}{ Extract } \\
\hline & Cell & Supernatant \\
\hline $12: 0$ & $0 \cdot 03 \pm 0 \cdot 01$ & 0.00 \\
\hline $13: 0$ & $0.06 \pm 0.02$ & $0 \cdot 00$ \\
\hline $14: 1 a$ & $0 \cdot 44 \pm 0 \cdot 01$ & $0 \cdot 00$ \\
\hline $14: 1 b$ & $0 \cdot 03 \pm 0.00$ & 0.00 \\
\hline $14: 0$ & $2 \cdot 10 \pm 0 \cdot 02$ & $0 \cdot 00$ \\
\hline $15: 1 \mathrm{a}$ & $0.45 \pm 0.02$ & 0.00 \\
\hline $15: 1 b$ & $0.08 \pm 0.01$ & 0.00 \\
\hline $15: 0$ & $0.90 \pm 0.01$ & 0.00 \\
\hline $16: 0 \mathrm{i}$ & $0 \cdot 13 \pm 0 \cdot 01$ & $0 \cdot 00$ \\
\hline $16: 1 \omega 9 c$ & $0.58 \pm 0.04$ & $0 \cdot 00$ \\
\hline $16: 1 \omega 7 c$ & $47 \cdot 47 \pm 0.76$ & $23 \cdot 47 \pm 0.53$ \\
\hline $16: 1 \omega 7 t$ & $6.69 \pm 0.06$ & $0 \cdot \overline{00}$ \\
\hline $16: 1 \omega 5 c$ & $0.35 \pm 0.13$ & $19 \cdot 51 \pm 6 \cdot 13$ \\
\hline $16: 0$ & $18 \cdot 31 \pm 0 \cdot 38$ & $46.99 \pm 7.53$ \\
\hline $17: 0 \mathrm{i}$ & $0 \cdot 01 \pm 0 \cdot 00$ & $0 \cdot 00$ \\
\hline $17: 0 \mathrm{a}$ & $3.54 \pm 0.03$ & $0 \cdot 00$ \\
\hline $17: 1 a$ & $0 \cdot 20 \pm 0 \cdot 00$ & $0 \cdot 00$ \\
\hline $17: 1 b$ & $0 \cdot 23 \pm 0 \cdot 01$ & 0.00 \\
\hline $17: 0$ & $1 \cdot 30 \pm 0 \cdot 07$ & $2 \cdot 84 \pm 4 \cdot 02$ \\
\hline 18 unknown & $0.04 \pm 0.00$ & 0.00 \\
\hline $18: 1 \omega 9 c$ & $0.36 \pm 0.01$ & $0 \cdot 00$ \\
\hline $18: 1 \omega 7 c$ & $14.46 \pm 0.29$ & $3 \cdot 15 \pm 4 \cdot 45$ \\
\hline $18: 1 \omega 7 t$ & $0.29 \pm 0.01$ & $0 \cdot 00$ \\
\hline $18: 1 \omega 5 c$ & $0.08 \pm 0 \cdot 03$ & 0.00 \\
\hline $18: 0$ & $1 \cdot 50 \pm 0.09$ & $4 \cdot 04 \pm 5 \cdot 72$ \\
\hline $18: 1 \mathrm{br}$ & $0.02 \pm 0.01$ & $0 \cdot \overline{00}$ \\
\hline $19: 1$ & $0 \cdot 17 \pm 0 \cdot 01$ & $0 \cdot 00$ \\
\hline $20: 1 \omega 9 c$ & $0 \cdot 16 \pm 0 \cdot 02$ & $0 \cdot 00$ \\
\hline $20: 0$ & $0.04 \pm 0.01$ & 0.00 \\
\hline
\end{tabular}

The colony and cellular morphology on different growth media showed that young colonies grow in punctiform with a diameter around $2 \mathrm{~mm}$ on TSB and LB 20 agar plates or 1 to $2 \mathrm{~mm}$ on VNSS plates. The colonies were smooth and convex with regular edges. However, the occurrence of pigmentation varied. After $24 \mathrm{~h}$ on VNSS medium, the colonies turned dark green, while on LB 20 and TSB the colonies remained white. Streaking white colonies from plates on VNSS plates gave dark green colonies after $24 \mathrm{~h}$ incubation and vice versa.

\section{Fatty acid analysis}

The unsaturated fatty acid $16: 1 \omega 7 c$ was shown to be the predominant fatty acid of $\mathrm{D} 2^{\mathrm{T}}$ cells (mean level, $47 \cdot 47 \pm 0 \cdot 76 \%$ ), whereas the fatty acids $16: 0,18: 1 \omega 7 c$ and $16: 1 \omega 7 t$ were the second, third and fourth most common fatty acids (relative percentages, $18 \cdot 31 \pm 0 \cdot 38$, $14.46 \pm 0.29$ and $6.69 \pm 0.06 \%$ ), respectively. These four major components accounted for almost $90 \%$ of the total cellular fatty acids. The balance of the profile of $\mathrm{D} 2^{\mathrm{T}}$ cells consisted of saturated and unsaturated fatty acids and a trace of terminally branched fatty acids. There was one unknown 18 carbon fatty acid, however, this constituted less than $1 \%$ of the profile. The supernatant also contained normal and monoenoic fatty acids but the biomass of the supernatant was four orders of magnitude less than that of the cells themselves. The saturated fatty acid 16:0 was the major fatty acid $(46.99 \pm 7.53)$ in the supernatant while $16: 1 \omega 7 c$ and $16: 1 \omega 5 c$ were the second and third most common fatty acids $(23.47 \pm 0.53$ and $19 \cdot 51 \pm 6 \cdot 13 \%)$, respectively (Table 2 ).

\section{DNA base composition}

The $\mathrm{G}+\mathrm{C}$ content of the DNA of Pseudoalteromonas tunicata was $42.2 \pm 0.7 \mathrm{~mol} \%$. The accepted range for members of the genus Pseudoalteromonas is 38 $50 \mathrm{~mol} \%$.

\section{$16 S$ rDNA sequence and phylogenetic characterization}

The sequencing strategy used in the current investigation generated 1370 bases of the $16 \mathrm{~S}$ rRNA gene between positions 34 and 1404 corresponding to the numbering of nucleotides in the $E$. coli $16 \mathrm{~S}$ rRNA molecule (Brosius et al., 1981). The resulting sequence was aligned to currently available 16S rRNA gene sequences which showed significant identity from the EMBL, GenBank and RDP databases. The derived multiple sequence alignment, including both conserved and variable domains of the $16 \mathrm{~S}$ rRNA primary structure, was used as the basis to generate pairwise similarities and genetic distances between $\mathrm{D} 2^{\mathrm{T}}$ and related bacteria. Several phylogenetic trees were constructed using different methods to analyse the sequence data, including genetic distance matrices and maximum parsimony. The input order of sequences into the various phylogenetic programs and the selection of outgroups were also varied during this study. Statistical evaluation of the derived genetic divergences was performed by bootsrap resampling of the sequence data.

The tree topology shown in Fig. 1 was identical to other statistical representations of the sequence data, including parsimony and consensus trees. Based on phylogenetic characterization, the strain $\mathrm{D} 2^{\mathrm{T}}$ belongs to the gamma-3 subclass of Proteobacteria and was most closely branched to the monophyletic cluster containing members of the genus Pseudoalteromonas. However, in relation to the Pseudoalteromonas clade, this strain comprised a distinct ancestral lineage, as seen in both parsimony (data not shown) and genetic distance trees (Fig. 1). The isolate shared 93\% 16S rDNA sequence similarity with $P$. citrea and $P$. aurantia. Within this genus, $\mathrm{D} 2^{\mathrm{T}}$ had a range of sequence identities between $91 \cdot 3-93.4 \%$, for the 


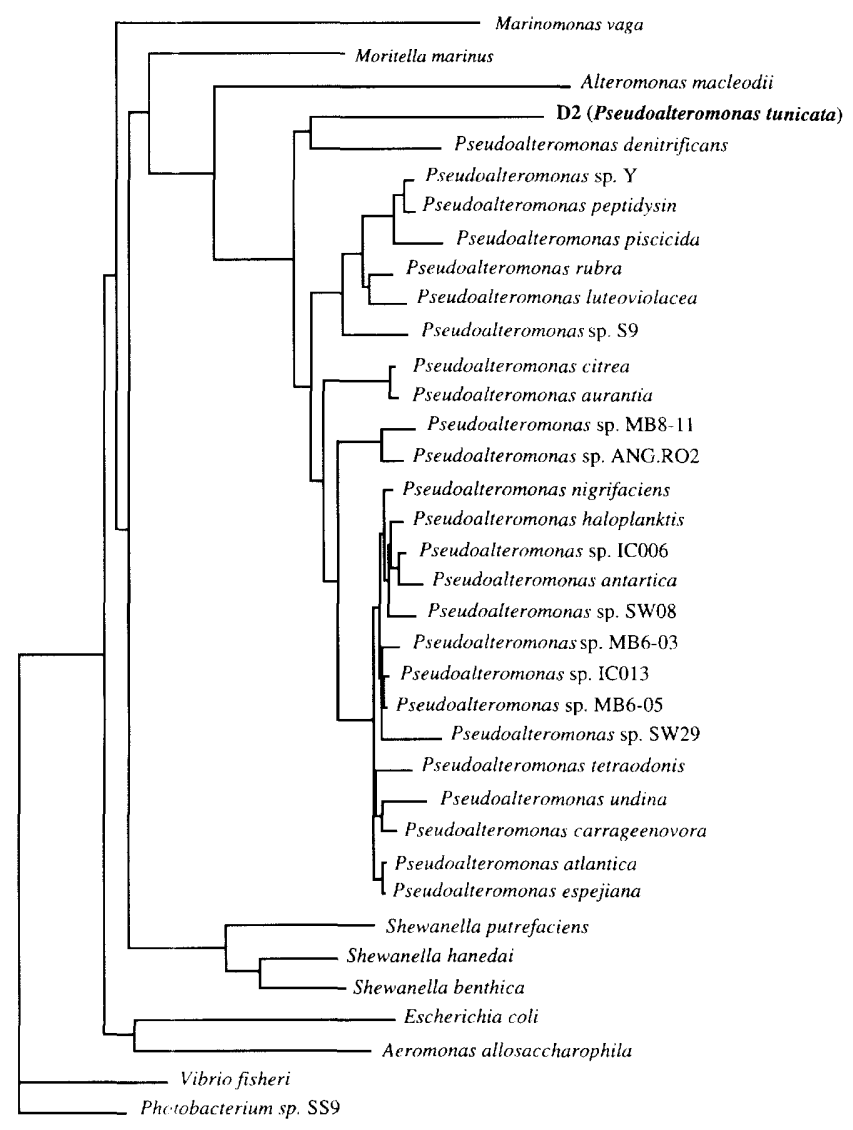

10

Fig. 1. Phylogenetic affiliations between $D 2^{\top}$ (P. tunicata), strains of the genus Pseudoalteromonas, and other closely related bacteria as indicated by near complete 165 rRNA gene sequence alignment. An alignment of 1370 characters was used to calculate genetic distances according to the method of Jukes \& Cantor (1969). The phenogram was reconstructed from the pairwise distance matrix using the neighbour-joining method of Saitou \& Nei (Satuito et al., 1996). The scale represents 1 base substitution per 10 nucleotide positions. Strain designations, source culture collections, and sequence database accession numbers are listed in the text.

Pseudoalt'romonas strains included in this analysis. The next highest sequence similarities to this genus was $88 \%$, for members of Shewanella and Moritella, and 87 and $85 \%$ for the genera Alteromonas and Marinomonas, respectively.

\section{DISCUSSION}

The strain that we investigated was isolated from an adult tunicate collected in Gullmarsfjorden on the western coast of Sweden. The isolate is a pigmented, motile and Gram-negative rod, with a $\mathrm{G}+\mathrm{C}$ content of $42 \cdot 2 \pm 0.7 \mathrm{~mol} \%$. Strain D2 ${ }^{\mathrm{T}}$ is oxidase-positive, can hydrolyse gelatin and requires $\mathrm{Na}^{+}$ion for growth with an optimal growth at $1-2 \% \mathrm{Na}^{+}$ion concentration. $\mathrm{D} 2^{\mathrm{T}}$ can grow at $4{ }^{\circ} \mathrm{C}$ but not at $37^{\circ} \mathrm{C}$ and is susceptible to all antibiotics tested. Strain $\mathrm{D} 2^{\mathrm{T}}$ possesses a sheathed flagellum which may disallow inclusion in the genus Pseudoalteromonas. However, earlier studies have suggested that similar bacteria with sheathed flagella may be admitted to the genus Pseudoalteromonas (Novic \& Tyler, 1985). Enger et al. (1987) also classified an isolate, $P$. denitrificans, with a sheathed flagellum to the genus Pseudoalteromonas. A further distinctive difference to the generic description of the genus Pseudoalteromonas is that $\mathrm{D} 2^{\mathrm{T}}$ is a facultative anaerobic bacterium, however, similar results have also been reported for $P$. denitrificans (Enger et al., 1987) and Pseudoalteromonas sp. S9 (Techkarnjanaruk et al., 1997; Wrangstadh et al., 1986). We therefore do not regard the presence of a flagellar sheath and the ability to grow anaerobically as decisive for exclusion of our strain from the genus Pseudoalteromonas.

The genus Pseudoalteromonas classification is somewhat unsatisfactory (Akagawa-Matsushita et al., 1993) given that the present members of this taxonomic group are related by $16 \mathrm{~S}$ rDNA sequence identities as low as $91 \%$. The $\mathrm{D} 2^{\mathrm{T}}$ isolate showed the highest similarities with $P$. citrea $(93.4 \%)$ and $P$. aurantia $(93.3 \%)$. These two species also have many characteristics in common with $P$. tunicata. When comparing 23 taxonomic parameters (Table 3 ) the proposed type strain of $P$. tunicata (D2 ${ }^{\mathrm{T}}$ ) differed by only six characteristics from the profiles of $P$. citrea and $P$. aurantia. All three species are pigmented, can hydrolyse gelatin, and can utilize mannose. None of the species can utilize sucrose, citrate, glycerol and sorbitol. In Table 3, the comparisons of characteristics between $P$. tunicata and other Pseudoalteromonas strains show that most strains differ by between nine and six characteristics except $P$. haloplanktis subsp. haloplanktis (12 characteristics) and Alteromonas macleodii (13 characteristics). The latter species also showed less than $90 \%$ similarities with D2 ${ }^{\mathrm{T}} 16 \mathrm{~S}$ rDNA sequence. With respect to evolutionary distances among strains assigned to genus Pseudoalteromonas the closest phylogenetic relative to $P$. tunicata is $P$. denitrificans. $P$. denitrificans has been classified to have a sheathed flagellum and can grow anaerobically. These strains, like D2 ${ }^{\mathrm{T}}$ cells, can show varied expression of pigment depending on the growth medium that is employed (Enger et al., 1987). This is a characteristic which is also expressed by Shewanella hanedai (Baumann et al., 1984) and P. nigrifaciens (Ivanova et al., 1996).

$P$. tunicata express at least one diffusable dark pigment when grown on the complex marine medium VNSS. The identity of the pigment(s) are not yet known but it was observed that the pigment was produced and released into the supernatant at the same time as the antilarval and antibacterial components. However, it has clearly been shown that the dark pigment produced by the bacterium is not a fouling-inhibitory component (Holmström et al., 1992). However, it is possible that the active components may be produced by the same pathway or by a branch of the pathway leading to the pigment production. The genus Pseudoalteromonas 
Table 3. Differential characteristics of Pseudoalteromonas species and Alteromonas macleodii

Data from references 4 and 12. +, Positive; - , negative; d, 11-89\% of the strains are positive; ND, not determined.

\begin{tabular}{|c|c|c|c|c|c|c|c|c|}
\hline Characteristic & P. tunicata & $\begin{array}{c}\text { P. haloplanktis } \\
\text { subsp. } \\
\text { haloplanktis }\end{array}$ & P. denitrificans & P. macleodii & P. undina & P. rubra & P. citrea & P. aurantia \\
\hline Growth at $44^{\circ} \mathrm{C}$ & t & - & + & & d & - & & + \\
\hline Growth at $35^{\circ} \mathrm{C}$ & t & d & - & + & - & + & d & - \\
\hline Pigmentation & + & - & + & - & & + & + & t \\
\hline Hydrolysis of gelatin & + & + & + & + & + & + & + & + \\
\hline \multicolumn{9}{|l|}{ Utilization of: } \\
\hline Mannose & + & + & ND & & - & + & + & + \\
\hline Sucrose & - & + & & + & + & - & - & \\
\hline Maltose & + & + & + & + & + & - & - & d \\
\hline Sorbitol & - & - & - & - & - & & & - \\
\hline Fructose & - & d & - & + & - & - & + & + \\
\hline Citrate & - & + & - & - & - & - & - & - \\
\hline Glycerol & - & - & - & + & - & & - & \\
\hline Galactose & -. & d & & + & - & & & - \\
\hline Laclose & - & - & - & + & -.. & - & & - \\
\hline Melibiose & - & - & ND & + & - & ND & - & \\
\hline Mannitol & - & d & - & d & - & - & - & \\
\hline Xylose & - & - & ND & d & - & -- & & - \\
\hline Trehalose & + & d & so & + & + & + & + & + \\
\hline Inositol & - & - & $\mathrm{ND}$ & & - & - & & \\
\hline Rhamnose & - & - & ND & $\cdots$ & - & - & - & \\
\hline Glycine & - & $d$ & ND & d & + & Ni) & ND & + \\
\hline L-Proline & + & d & + & - & d & ND) & - & - \\
\hline $\mathrm{J}-$ Histidine & - & d & ND & - & - & .ND & - & d \\
\hline Oxidase & + & + & + & + & + & + & + & + \\
\hline $\mathrm{G}+\mathrm{C}$ content $(\mathrm{mol} \%)$ & $42-43$ & $41-45$ & 37 & $43-44$ & $43-44$ & $46-48$ & 4145 & 3843 \\
\hline $\begin{array}{l}\text { No. of characteristics } \\
\text { differing from } P \text {. tunticata }\end{array}$ & & 12 & 9 & 13 & 7 & 6 & 6 & 6 \\
\hline
\end{tabular}

contains both pigmented and non-pigmented strains. Many of the strains within this genus produce metabolites active against other organisms. Five pigmented species belonging to Pseudoalteromonas have been found to produce inhibitory components. Four of these species, $P$. rubra, $P$. luteoviolacea, $P$. citre $a$ and $P$. aurantia have been shown to produce high-molecular-mass components which are autotoxic and active against both Gram-positive and Gram-negative bacteria (Baumann et al., 1984). This is a characteristic which $P$. tunicata also possesses (James et al., 1996). The fifth species, $P$. piscida, has been suggested to cause fish death (Bein, 1954). Furthermore, the non-pigmented $P$. haloplanktis subsp. tetraodonis (Akagawa-Matsushita et al., 1993; Simidu et al., 1990) has been found to produce tetrodotoxin (Simidu et al., 1990). P. denitrificans can also produce autotoxic substances that kill cells and inhibit growth in dense bacterial cultures (Enger et al., 1987). Specific biological activity has furthermore been demonstrated for other Pseudoalteromonas strains. Pseudoalteromonas sp. S9 and Pseudoalteromonas colwelliana have been shown to contribute to larval settlement (Szewzyk et al., 1991; Weiner et al., 1988).

$P$. tunicata cells are dominated by monoenoic fatty acids $(>70 \%)$ which is typical of Gram-negative bacteria. The fatty acids $16: 1 \omega 7 c$ and $16: 0$ were the dominant fatty acids in both the cell and the supernatant extracts. These two fatty acids were also the dominant molecules when $\mathrm{D} 2^{\mathrm{T}}$ was grown in Tryptone soy broth complemented with $2 \%(\mathrm{w} / \mathrm{v}) \mathrm{NaCl}$ (data not shown). This result is in agreement with the findings by Bozal et al. (1997) who performed a fatty acid analysis on Pseudoalteromonas antarctica species. They showed that the two fatty acids, $16: 1 \omega 7 \mathrm{c}$ and 16:0, were the dominant components. Svetashev et al. (1995) determined cellular fatty acid composition of seven type strains of Pseudoalteromonas species. They also showed that the fatty acids $16: 1 \omega 7 \mathrm{c}$ and 16:0 were the main components. In addition, only low amounts of branched-chain and hydroxy fatty acids were detected in the seven type strains (Svetashev et al., 1995). These results are in agreement with the data on the fatty acid composition of $P$. tunicata cells.

\section{Description of Pseudoalteromonas tunicata}

Pseudoalteromonas tunicata (tu.ni.ca'ta L. fem. n. tunicata shirt-like classical piece of Roman underwear, tunic; L. fem. adj. tunicata clothed with a tunic).

Facultative anaerobic Gram-negative rod shaped cells that are $2 \cdot 0-3 \cdot 4 \mu \mathrm{m}$ in length. Motile by means of a polar sheathed flagellum. Growth on VNSS medium results in dark-green-pigmented colonies while growth on TSB medium results in white colonies. Does not ferment sugar in the Hugh-Leifson test. Sodium ions are required for growth with the optimal $\mathrm{NaCl}$ concentration of $1-2 \%$. Cannot grow at $\mathrm{pH} 5$ or 11 ; optimal $\mathrm{pH}$ range for growth is $\mathrm{pH} 7-8$. Slow growth occurs at $4{ }^{\circ} \mathrm{C}$ and no growth is detectable at $37^{\circ} \mathrm{C}$. Oxidase- and catalase-positive. Utilizes trehalose, glu- 
cose, maltose and Tween 20 at a concentration of $4 \mathrm{~g} \mathrm{l}^{-1}$ but can not grow on galactose, fructose, xylose, sucrose, lactose, raffinose, melibiose, glycerol, mannitol, rhamnose, sorbitol, inositol, dulcitol, melexitose, xylitol, erythritol, glycine, threonine, arabinose, Laspargine and L-histidine. Positive for hydrolysis of gelatin. Sensitive to erythromycin, rifampicin, gentamicin, tetracycline, ampicillin, neomycin, kanamycin and nalidixic acid at a concentration of $100 \mu \mathrm{g} \mathrm{ml}^{-1}$ and is sensitive to the vibriostatic agent $0 / 129$ at a concentration of $150 \mu \mathrm{g} \mathrm{ml}^{-1}$. The $\mathrm{G}+\mathrm{C}$ content of the DNA is $42 \cdot 2 \pm 0.7 \mathrm{~mol} \%$. The main cellular fatty acids are $16: 1 \omega 7 c, 16: 0,18: 1 \omega 7 c$ and $16: 1 \omega 7 t$, respectively. Strain $\mathrm{D} 2^{\mathrm{T}}$ is negative for $\mathrm{H}_{2} \mathrm{~S}$ and $\mathrm{NO}_{2}$ production and no $\beta$-galactosidase, arginine dihydrolase, lysine decarboxylase and ornithine decarboxylase activity has been detected. Isolated from an adult tunicate, Ciona intestinalis, collected from water off the western coast of Sweden. The type strain has been deposited in the Culture Collection of University of Göteborg as strain CCUG $26757^{\mathrm{T}}$.

\section{ACKNOWLEDGEMENTS}

This work was supported by the Australian Research Council and Swedish National Board for Industrial and Technical Development. We thank Aaron Peacock for his technical assistance with the fatty acid analysis and John Bowman for determing the $\mathrm{G}+\mathrm{C}$ content.

\section{REFERENCES}

Akagawa-Matsushita, M., Koga, Y. \& Yamasato, K. (1993). DNA relatedness among nonpigmented species of Alteromonas and synonymy .Alteromonas haloplanktis (Zobell and Upham 1944) Reichelt and Baumann 1973 and Alteromonas tetraodonis Simidu et al. 1990. Int J Syst Bacteriol 43, 500-503.

Bauer, A. N., Kirby, W. M. M., Sherry, J. C. \& Turck, M. (1966). Antibiotic susceptibility testing by a standard single disc method. Am J Clin Pathol 45, 493-496.

Baumann, L., Baumann, P., Mandel, M. \& Allen, R. D. (1972). Taxonomy of aerobic marine eubacteria. $J$ Bacteriol $\mathbf{1 1 0}$, 402-429.

Baumann, P., Gauthier, M. J. \& Baumann, L. (1984). Bergey's Manual of Determinative Bacteriology, 9th edn. Baltimore: Williams \& Wilkins.

Bein, S.J. (1954). A study of certain chromogenic bacteria isolated from "red tide" water with a description of a new species. Bull Mar Sci Gulf Caribb 4, 110-119.

Bligh, E. G. \& Dyer, W. J. (1959). A rapid method of total lipid extraction and purification. Can J Biochem Physiol 37, 911-917.

Bozal, N., Tudela, E., Rossello-Mora, R., Lalucat, J. \& Guinea, J. (1997). Pseudoalteromonas antarctica sp. nov., isolated from an Antarctic coastal environment. Int J Syst Bacteriol 47, 345-351.

Brosius, J., Palmer, M. L., Kennedy, P. J. \& Noller, H. F. (1978). Complete nucleotide sequence of a 16S ribosomal RNA gene from Escherichia coli. Proc Natl Acad Sci USA 75, 4801-4805.

Clark, J. D. \& Maaloe, O. (1967). DNA replication and the division cycle in Escherichia coli. J Bacteriol 151, 1568-1580.

Deming, J. W., Somers, L. K., Straube, W. L., Swartz, D. G. \& MacDonell, M. T. (1988). Isolation of an oligatory barophilic bacterium and description of a new genus, Colwellia gen. nov. Syst Appl Microbiol 10, 152-160.

Egan, S. (1995). Inhibition of algal spores germination by marine bacteria. Honors thesis, University of New South Wales.

Enger, O., Nygaard, H., Solberg, M., Schei, G., Nielsen, J. \& Dundas, I. (1987). Characterization of Alteromonas denitrificans sp. nov. Int J Syst Bacteriol 37, 416-421.

Felsenstein, J. (1989). PHYLIP: phylogeny inference package. Cladistics 5, $164-166$.

Gauthier, G., Gauthier, M. \& Christen, R. (1995). Phylogenetic analysis of the genera Alteromonas, Shewanella, and Moritella using genes coding for small-subunit rRNA sequences and division of the genus Alteromonas into two genera, Alteromonas (emended) and Pseudoalteromonas gen. nov., and proposal of twelve new species combination. Int $J$ Syst Bacteriol 45, 755-761.

Givskov, M., De Nys, R., Manefield, M., Gram, L., Maximilien, R., Eberl, L., Molin, S., Steinberg, P. \& Kjelleberg, S. (1996). Eukaryotic interference with homoserine lactone mediated procaryotic signalling. $J$ Bacteriol 178, 6618-6622.

Guckert, J. B., Antworth, C. P., Nichols, P. D. \& White, D. C. (1985). Phospholipid, ester-linked fattyacid profiles as reproducible assays for changes in prokaryotic community structure of estuarine sediments. FEMS Microb Ecol 31, 147-158.

Hallbeck, L., Ståhl, F. \& Pedersen, K. (1993). Phylogeny and phenotypic characterization of stalk forming and iron-oxidizing bacterium Gallionella ferruginea. $J$ Gen Microbiol 139, 1531-1535.

Holmström, C., Rittschof, D. \& Kjelleberg, S. (1992). Inhibition of settlement by larvae of Balanus amphitrite and Ciona intestinalis by a surface-colonizing marine bacterium. Appl Environ Microbiol 58, 2111-2115.

Holmström, C. (1993). Regulation of settlement of marine invertebrate larvae by bacterial extracellular components. $\mathrm{PhD}$ thesis, University of Göteborg.

Holmström, C. \& Kjelleberg, S. (1994). The effect of external biological factors on settlement of marine invertebrate and new antifouling technology. Biofouling 8, 147-160.

Holmström, C., James, S., Egan, S. \& Kjelleberg, S. (1996). Inhibition of common fouling organisms by marine bacterial isolates with special reference to the role of pigmented bacteria. Biofouling 10, 251-259.

Holmström, C., James, S., Egan, S. \& Kjelleberg, S. (1997). Regulation of activity and settlement of marine organisms by bacterial extracellular components. In Proceedings of USPacific Rim Workshop on Emerging Nonmetallic Materials for the Marine Environment, Honolulu, section 3.16-3.20. Washington, DC: US Office of Naval Research.

Hugh, R. \& Leifson, E. (1953). The taxonomic significance of fermentative versus oxidative metabolism of carbohydrates by various gram-negative bacteria. $J$ Bacteriol 66, 24-26.

Ivanova, E. P., Kiprianova, E. A., Mikhailov, V. V., Levanova, G. F., Garagulya, A. D., Gorshikova, N. M., Yumoto, N. \& Yoshikawa, S. (1996). Characterization and identification of marine Alteromonas nigrifaciens strains and emendation of the description. Int J Syst Bacteriol 46, 223-228.

James, S., Holmström, C. \& Kjelleberg, S. (1996). Purification and characterization of a novel antibacterial protein from the marine bacterium D2. Appl Environ Microbiol 62, 2783-2788.

Johnson, J. L. (1994). DNA sequence similarities. In Methods for General and Molecular Bacteriology, pp. 664-665. Edited by 
P. Gerhardt, W. A. Wood \& N. R. Krieg. Washington, DC: American Society for Microbiology.

Jukes, T. H. \& Cantor, C. R. (1969). Evolution of protein molecules. In Mammalian Protein Metabolism, pp. 21-132. Edited by H. N. Munro. New York: Academic Press.

Kita-Tsukamoto, K., Oyaizu, H., Nanba, K. \& Simidu, U. (1993). Phylogenetic relationships of marine bacteria, mainly members of the family Vibrionaceae, determined on the basis of $16 \mathrm{~S}$ rRNA sequences. Int $J$ Syst Bacteriol 43, 8-19.

Kovaks, N. (1956). Identification of Pseudomonas pyocyanea by the oxidase reaction. Nature 178, 703 .

MacDonell, M. T. \& Colwell, R. R. (1985). Phylogeny of the Vibrionaceae and recommendation for two new genera, Listonella and Shewanella. Syst Appl Microbiol 6, 171-182.

Novic, N. J. \& Tyler, M. E. (1985). Isolation and characterization of Alteromonas luteoviolaceae strains with sheathed flagella. Int $J$ Syst Bacteriol 35, 111-113.

Östling, J., Goodman, A. \& Kjelleberg, S. (1991). Behaviour of IncP-1 plasmids and a miniMu transposon in a marine Vibrio sp. isolation of starvation inducible lac operon fusions. FEMS Microbiol Ecol 86, 83-94.

Saitou, N. \& Nei, M. (1987). The neighbor-joining method: a new method for reconstructing phylogenetic trees. Mol Biol Evol 4 , 406-425.

Simidu, U., Kita-Tsukamoto, K., Yasumoto, T. \& Yotsu, M. (1990). Taxonomy of four marine bacterial strains that produce tetrodotoxin. Int J Syst Bacteriol 40, 331-336.

Skerman, V. B. D. (1967). A guide to the identification of the genera of bacteria. In Abstracts of Microbiological Methods, p. 147. Edited by V. B. D. Skerman. New York: Wiley.

Svetashev, V. J., Vysotskii, M. V., Ivanova, E. P. \& Mikhailov, V. V.
(1995). Cellular fatty acids of Alteromonas species. Syst Appl Microbiol 18, 37-43.

Szewzyk, U., Holmström, C., Wrangstadh, M., Samuelsson, M.-O., Maki, J. S. \& Kjelleberg, S. (1991). Relevance of the exopolysaccharide of marine Pseudomonas sp. strain S9 for the attachment of Ciona intestinalis larvae. Mar Ecol Prog Ser 75. 259-265.

Techkarnjanaruk, S., Pongpattanakitshote, S. \& Goodman, A. (1997). Use of a promoterless $l a c Z$ gene insertion to investigate chitinase gene expression in the marine bacterium Pseudoalteromonas sp strain S9. Appl Environ Microbiol 63, 2989-2996.

Thompson, J. D., Higgins, D. G. \& Gibson, T. J. (1994). CLUSTAL $\mathrm{W}$ : improving the sensitivity of progressive multiple sequence alignment through sequence weighting, position specific gap penalties and weight matrix choice. Nucleic Acids Res 22. 4673-4680.

Weiner, R. M., Coyne, V. E., Brayton, P. P. \& Raiken, S. F. (1988). Alteromonas colwelliana sp. nov., an isolate from oyster habitats. Int J Syst Bacteriol 38, 240-244.

White, D. C., Nickels, J. D., King, J. D. \& Bobbie, R. J. (1979). Determination of the sedimentary microbial biomass by extractable lipid phosphate. Oecologia (Berlin) 40, 51-62.

Wilson, K. (1992). Preparation and analysis of DNA. In Current Protocols in Molecular Biology, section 2.4.1. Edited by F. M. Ausubel, R. Brent, R. E. Kingston, D. D. Moore, J. G. Seidman, J. A. Smith \& K. Struhl. Boston: Wiley.

Wisconsin Package (1994). Version 8 program manual. Genetics computer group. 575 Science Drive, Madison, Wisconsin, USA.

Wrangstadh, M., Conway, P. L. \& Kjelleberg, S. (1986). The production and release of an extracellular polysaccharide during starvation of a marine Pseudomonas sp. and the effect thereof on adhesion. Arch Microbiol 145, 220-227. 